\title{
Implementasi Augmanted Reality sebagai Media Pengenalan Sains Sederhana Pada Anak Usia Dini
}

\author{
Erna \\ TK Aisiyah Batusangkar, erna.tkababsk@gmail.com
}

\begin{abstract}
This study aims to determine the increasing knowledge of simple science in Early Childhood in Kindergarten-right Aisyiyah Batusangkar after using Augmanted Reality technology as learning media. The type of research conducted is classroom action research. The research methodology that used in this reasearch was mixed methodology with qualitative and quantitative approach with research subject is 20 children of group B I kindegarten. The technique used in data collection and data analysis in the form of observation and subsequent interview is processed by quantitative descriptive analysis in SPSS. This classroom action research is conducted in two cycles, namely first cycle and second cycle. The introduction of children's Science in first cycle was generally still low with the average value reaches $65 \% \%$, then second cycle plan is revised again and The increasing reaches $99 \%$ average value, positive with an increase of $34 \%$.
\end{abstract}

Keywords: Augmented Reality, science, playing early age

\begin{abstract}
Abstrak
Penelitian ini bertujuan untuk mengetahui peningkatan pengetahuan sains sederhana pada Anak Usia Dini di Taman Kanakkanan Aisyiyah Batusangkar setelah penggunaan teknologi Augmanted Reality sebagai media pembelajaran. Jenis penelitian y ang dilaksanakan adalah penelitian tindakan kelas, metodologi penelitian y ang dipakai adalah metodologi campuran (Mixing Method) dengan pendekatan kualitatif dan kuantitatif dengan subjek penelitian Taman Kanak-kanak Aisyiyah Batusangkar pada kelompok B I y ang berjumlah 20 orang anak. Teknik y ang digunakan dalam pengumpulan data dan analisis data berupa observasi dan wawancara selanjutnya diolah dengan analisis deskriptif kuantitatif pada SPSS. Penelitian tindakan kelas ini dilakukan dalam dua siklus yaitu siklus I dan siklus II. Pengenalan Sains anak pada siklus I pada umumnya masih rendah dengan nilai rata-rata mencapai $65 \% \%$, selanjutnya rencana siklus II direvisi kembali dan pada siklus II peningkatan pengenalan sains anak jadi lebih meningkat yaitu mencapai nilai rata-rata $99 \%$, serta menunjukkan hasil yang positif dengan peningkatan sebesar $34 \%$.
\end{abstract}

Kata kunci: Augmanted Reality, sains, bermain usia dini

(C) 2018 Jurnal RESTI

\section{Pendahuluan}

Pendidikan Anak Usia Dini adalah suatu upaya pembinaan yang ditujukan kepada anak sejak lahir sampai usia enam tahun yang dilakukan melalui pemberian rangsangan pendidikan untuk membantu pertumbuhan dan perkembangan jasmani dan rohani, agar anak memiliki kesiapan dalam memasuki pendidikan lebih lanjut[1]. Selain itu, Peraturan Menteri Pendidikan Nasional Nomor 137 Tahun 2014 tentang Standar Nasional Pendidikan Anak Usia Dini dan tingkat pencapaian perkembangan menggambarkan pertumbuhan dan perkembangan yang diharapkan dicapai anak pada rentang usia tertentu.

Ruang lingkup pengembangan pembelajaran di Taman Kanak-kanak di bagi ke dalam bidang pengembangan pembiasaan prilaku dan bidang kemampuan dasar. Selanjutnya dijelaskan bahwa bidang pengembangan pembiasaan perilaku merupakan kegiatan yang dilakukan secara terus menerus dalam kehidupan seharihari, sedangkan bidang pengembangan kemampuan dasar merupakan kegiatan yang dipersiapkan oleh guru untuk meningkatkan kemampuan kognitif, bahasa, fisik /motorik.

Pengembangan pembelajaran sains pada anak usia taman kanak-kanak mempunyai peran yang sangat penting dalam menstimulasi kognitif, membantu meletakkan dasar kemampuan dalam pembentukan sumber daya manusia yang diharapkan. Pengembangan pembelajaran sains di Taman Kanak-kanak dikembangkan melalui kegiatan bermain, karena masa

\begin{tabular}{|l|l|l|} 
Diterima Redaksi : 02-04-2018 & Selesai Revisi : 18-04-2018 & Diterbitkan Online : 26-04-2018
\end{tabular} 
kanak-kanak adalah masa bermain sebagaimana prinsip sehingga anak tertarik dalam pembelajaran sains yang belajar di Taman kanak-kanak yaitu: "Bermain sambil menyenangkan dan potensi anak pun tergali secara belajar dan belajar seraya bermain".Kognitif merupakan maksimal, tentunya tidak cukup dengan media yang suatu proses berfikir, yaitu kemampuan individu untuk menarik saja tetapi diiringi dengan metode dan teknik menghubungkan, menilai dan mempertiambangkan yang tepat.

suatu kejadian atau peristiwa. Proses kognitif berhubungan dengan tingkat kecerdasan (Inteligensi) yang mencirikan sesorang dengan berbagai minat terutama sekali ditujukan kepada ide-ide dalam belajar[2].

Pembelajaran sains bagi anak-anak adalah segala sesuatu yang menakjubkan, sesuatu yang ditemukan dan dianggap menarik serta memberikan pengetahuan atau merangsang untuk mengetahui dan menyelidikinya.

Berdasarkan hasil pengamatan peneliti di Taman Kanak-kanak Aisyiyah Batusangkar pada Tahun Ajaran 2017/2018 pada semester I di kelompok B I kemampuan kognitif anak terhadap pemahaman konsep sains kurang berkembang. Sebagian besar anak belum mampu mengklasifikasikan benda berdasarkan fungsi, bers ikap eksploratif terhadap benda, ataupun memprediksi urutan berikutnya.

Secara konseptual terdapat sejumlah pengertian dan Permasalahan utama yang menyebabkan hal tersebut batasan sains yang dikemukakan para ahli terkait adalah kurangnya media pembelajaran yang menarik pengertian sains. Sains didefinisikan sebagai bidang serta strategi yang digunakan oleh guru kurang ilmu alamiah dengan ruang lingkup zat dan energi, baik maksimal sehingga berdampak pada kurangnya minat yang terdapat pada makluk hidup maupun makluk tak anak dalam proses pembelajaran sains yang disediakan. hidup, sedangkan James Conant menyebut sains sebagai Pembelajaran sains selalu terkait dengan media untuk satu deretan konsep serta skema konseptual yang bereksplorasi sehingga keterbatasan media berhubungan satu sama lain yang tumbuh sebagai hasil pembelajaran secara langsung memiliki pengaruh serangkaian percobaan dan pengamatan serta dapat terhadap pengembangan pengetahuan sains anak. Anak diamati dan diuji coba lebih lanjut[3].

Pembelajaran sains dapat merangsang aspek menjadi tidak berminat dan cepat bosan saat pembelajaran sains, anak cenderung melakukan perkembangan anak seperti perkembangan kognitif, kegiatan hanya yang berkaitan dengan menulis dan afektif, psikomotorik, dan kreatifitas anak berhitung.

pengembangan kognitif merupakan hasil belajar yang Salah satu metode yang dapat diterapkan untuk bersifat intelektual atau pengetahuan, adapun afektif mengatasi permasalahan ini adalah melalui permainan berkenan dengan sikap, selanjutnya psikomotorik atau metode bermain. Metode bermain adalah suatu cara berkenaan dengan keterampilan dan kemampuan mengajar melalui bermacam-macam bentuk kegiatan bertindak. Oleh karena itu, peran media pembelajaran yang memberikan kesenangan atau kepuasan pada diri berupa alat permainan edukatif yang digunakan sebagai anak yang bersifat nonserius dan bahan mainan sarana belajar di Taman Kanak-kanak sangat penting, terkandung dalam kegiatan yang secara imajinatif karena alat permainan yang memenuhi syarat-syarat ditransformasi oleh orang dewasa sesuai dengan akan menentukan terjadinya proses pembelajaran yang kebutuhannya. Metode bermain dapat memuaskan bermutu.

Pembelajaran sains di Taman Kanak-kanak yang terpenting bukannya menyerap pengetahuan sebanyaktuntutan dan kebutuhan perkembangan dimensimotorik, kognitif, kreatifitas, emosi, sosial, nilai, bahasa dan sikap hidup.

banyaknya, melainkan bagaimana anak dapat mengingat Semua aspek perkembangan anak dapat ditingkatkan dan mengendapkan pengalaman yang diperoleh, serta melalui bermain. Anak dapat berekspresi dan bagaimana anak menggunakan konsep dan prinsip yang bereksplorasi untuk memperkut hal-hal yang sudah dipelajarinya itu dalam lingkup kehidupannya atau diketahui dan menemukan hal-hal baru serta belajarnya Jika anak diharapkan menguasai konsep- mengembangkan potensi secara optimal, baik potensi konsep terkait dengan sains, maka guru harus fisik maupun mental intelektual dan spiritual, bermain memfasilitasi mereka dalam menguasainya melalui merupakan jembatan bagi perkembangan semua aspek observasi, demonstrasi, diskusi, percobaan atau anak[4].

eksperimen dengan media yang relevan. Ketika guru membimbing pembelajaran sains, perasaan anak berkembang tentang apa yang dipelajarinya dan dapat ditemukan disemua tempat di sekolah di rumah dan sebagainya.

Perkembangan teknologi informasi telah menginisiasi lahir dan berkembangnya Augmanted Reality sehingga pemanfaatannya pun merambah pada berbagai bidang, salah satunya adalah pendidikan. Augmanted Reality adalah cara baru dan menyenangkan dimana manusia

Dari uraian di atas dapat kita lihat bahwa peran guru berinteraksi dengan komputer, karena dapat membawa untuk memfasilitasi terjadinya perkembangan objek virtual ke lingkungan pengguna, memberikan kemampuan berfikir anak sangat penting. Untuk itu pengalaman visualisasi yang nyata[5]. guru dituntut mempunyai kreatifitas yang tinggi dalam menciptakan media pembelajaran yang inovatif, 
Berdasarkan latar belakang yang telah diuraikan di atas, keterampilan menghitung, mengenal bentuk dan warna maka tertarik untuk melakukan penelitian yang berjudul untuk merangsang anak berfikir secara logis agar anak "Pengenalan Sains Sederhana Pada Anak Usia Dini aktif, kreatif dan menyenangkan dalam penbelajaran Melalui Media Augmanted Reality di Taman Kanak- sains. Melalui permainan dengan media Augmanted kanak Aisyiyah Batusangkar."

Adapun rumusan masalah dalam penelitian ini adalah "Bagaimana peningkatan pengetahuan sains sederhana Anak Usia Dini di Taman Kanak-kanak Aisyiyah Batusangkar melalui media Augmanted Reality?". Tujuan penelitian ini antara lain yaitu untuk mengetahui peningkatan pengetahuan sains sederhana pada Anak Usia Dini di Taman Kanak-kanan Aisyiyah Batusangkar setelah penerapan permainan melalui media Augmanted Reality.

\section{Tinjauan Pustaka}

\subsection{Anak Usia Dini}

Reality ini dapat berkontribusi bagi pembelajaran sains anak berupa pengalaman langsung yang lebih membekas, menyenangkan, berkesan, membangun sikap positif, kerja sama, dan mengundang rasa ingin tahu yang besar sehingga aspek perkembangan anak dapat berkembang secara optimal mungkin

\section{Metodologi Penelitian}

Penelitian ini merupakan penelitian berbentuk penelitian tindakan kelas. Penelitian tindakan kelas adalah penelitian yang berupaya meningkatkan kualitas proses dan hasil belajar melalui suatu tindakan berbentuk siklus berdasarkan pencermatan guru yang mendalamterhadap permasalahan yang terjadi dan berkeyakinan akan

Anak usia dini adalah anak usia lahir hingga 6 tahun mendapatkan solusi terbaik bagi siswa di lingkungan yang berada dalam proses pertumbuhan dan kelasnya sendiri[9]. Penelitian dilakukan pada perkembangan yang bersifat unik, artinya memiliki pola kelompok B I Taman Kanak-kanak Aisyiyah pertumbuhan dan perkembangan fisik (koordinasi Batusangkar Tahun Ajaran 2017/2018 yang motorik halus dan kasar), kecerdasan (daya pikir daya dilaksanakan pada semester I (ganjil) dengan jumlah cipta, kecerdasan emosi, kecerdasan emosi kecerdasan anak 20 orang yang terdiri dari 9 orang laki-laki dan 11 spiritual) sosial-emosional (sikap dan perilaku serta orang perempuan. Metodologi penelitian yang agama), bahasa dan perkembangan yang sedang dilalui digunakan adalah metodologi Mixing Method oleh anak tersebut[6]. Perkembangan fisik anak ditandai (metodologi campuran) dengan pendekatan kualitatif dengan keaktifan anak untuk melakukan kegiatan yang dan kuantitatif. Adapun variabel dalam penelitian terdiri bermanfaat untuk pengembangan otot kecil maupan otot dari dua variabel yaitu variabel bebas dan variabel bes ar[7].

Usia 0-6 tahun merupakan The Golden Age (Masa emas) yang hanya datang sekali dan tidak dapat diulang, perkembangan yang terjadi dimasa awal cenderung permanen dan mempengaruhi sikap dan perilaku anak sepanjang hidupnya. anak usia dini merupakan masa pertumbuhan dan perkembangan yang sangat penting, oleh sebab itu perlu memberikan stimulasi, rangsang dan motivasi sehingga pada saat yang tepat aspek-aspek perkembangan anak dapat berkembang secara optimal dimana hasil ini akan berpengaruh besar terhadap kualitas anak dimasa dewasanya[8]. Hal ini menunjukkan bahwa melakukan pendidikan berupa pengenalan sains sederhana dengan cara-cara yang sesuai dengan pola perkembangan anaks angat baikbagi perkembangan kemampuan kognitif anak.

\subsection{Augmanted Reality}

Augmanted Reality (AR) adalah kombinasi antara dunia maya (virtual) dan dunia nyata (real) yang dibuat oleh komputer. Objek virtual dapat berupa teks, animasi, model 3D atau video yang dihubungkan dengan lingkungan sebenarnya sehingga pengguna merasakan objek virtual di lingkungannya. Pemanfaatan teknologi Augmanted Reality ini dapat dilakukan dengan tujuan untuk pengenalan sains serderhana kepada anakusia dini berupa pengelompokkan benda, melakukan percobaan mengembangkan dan melatih motorik halus, terikat. Variabe bebas dalam penelitian ini adalah metode bermain menggunakan Augmanted Reality sedangkan variabel terikatnya adalah kemampuan kognitif dalam pengetahuan sains sederhana.

Penelitian tindakan kelas diarahkan kepada usaha guru dalam memperbaiki dan meningkatkan pembelajaran yang dilaksanakan dalam proses belajar mengajar di dalam kelasnya sendiri dengan melibatkan anak didik melalui tindakan yang direncanakan, dilaksanakan dan dievaluasi, serta memperbaiki kinerja sebagai guru dalam melaksanakan kegiatan belajar mengajar.

Penelitian tindakan kelas ini dilaksanakan dalam dua siklus, yaitu siklus I dan siklus II yang dimulai pada siklus pertama dengan tiga kali pertemuan dan siklus kedua tiga kali pertemuan untuk siklus kedua sangat ditentukan hasil refleksi pertama. Penelitian dilakukan melalui proses yang dinamis dan komplementari yang terdiri dari empat momentum esensial yaitu pertama, perencanaan.

Tahap perencanaan adalah merupakan awal pelaksanaan penelitian dengan tujuan agar tindakan yang dilakukan dapat terlaks ana secara terarah dengan tujuan yang jelas; Tahap kedua, pelaksanaan. Tindakan utama dalam pelaksanaan pembelajaran adalah yang telah dituangkan dalam rencana kegiatan hariaan mulai dari kegiatan awal sampai kegiatan akhir ; ketiga : Observasi dan Evaluasi. Observasi dilakukan secara bersamaan saat pelaksanaan 
proses belajar berlangsung. pengamatan merupakan serangkaian kegiatan mengenali, merekam, mendokumentasikan dan mengamati perubahanperubahan yang terjadi dan hasil yang dicapai sebagai dampak dari tindakan yang dilakukan. Observasi ini bertujuan untuk mengumpulkan data selama penelitian berlangsung yang tertera dalam format observasi ; dan tahap keempat : Refleksi. Merefleksi berarti mencoba melihat dan merenungkan kembali apa yang telah dilakukan dan apa hasilnya terhadap proses belajar, Untuk melakukan analisis terhadap peningkatan untuk mengetahui kelemahan dan kekuatan dari pengetahuan sains anak antara sebelum tindakan kelas tindakan yang telah kita lakukan. Merumuskan tindakan dengan sesudah tindakan penggunaan media Augmanted yang perlu dilakukan selanjutnya dan menjelaskan bagai Reality dapat dilakukan uji T Paired dengan penggunaan mana melakukannya. Perhatikan Gambar 1.

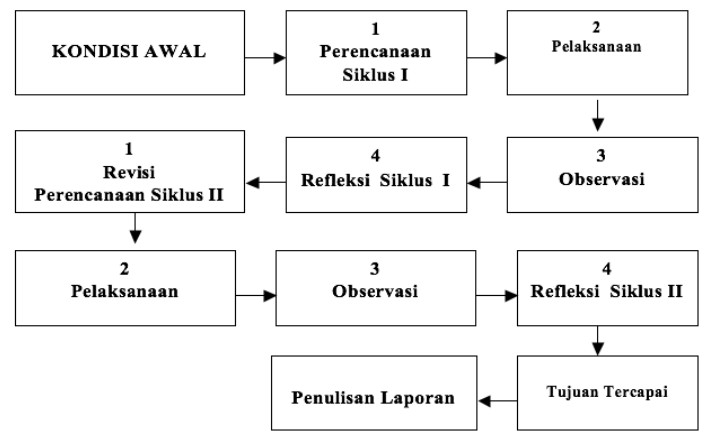

Gambar 1. Siklus PT K

Pengumpulan data pada penelitian ini dilakukan melalui 3 (tiga) cara berikut, yaitu Teknik Observasi, Teknik Wawancara dan Teknik Dokumentasi. Data yang telah dikumpulkan diolah dengan menggunakan dua metode analisis data yaitu lembaran observasi hasil pengamatan anak dan analisis statistik deskriptif kuantitatif.

Pengolahan data dari lembaran observasi dilakukakan dengan mengolah data yang diperoleh selama penelitian berlangsung dianalisis untuk memperoleh hasil yang maksimal terhadap penelitian tindakan kelas yang telah dilakukan. Hasil analisis ini dimasukkan kedalam lembaran observasi data yang diperoleh selama proses pembelajaran diolah dengan teknik persentase[10] yaitu

$$
\mathrm{A}=\frac{\mathrm{F}}{\mathrm{N}} \times 100 \%
$$

Keterangan

$\mathrm{A}=$ Aktivitas anak

$\mathrm{F}=$ Jumlah anak yang terlibat dalam setiap aspek

$\mathrm{N}=$ Jumlah anak dalam satu kelas

Analisis deskriptif kuantitatif adalah cara pengolahan data yang dilakukan dengan menganalisa data angka agar dapat memberikan gambaran secara ringkas dan jelas sehingga dapat ditarik pengertian dan makna tertentu. Peningkatan aktivitas anak ditentukan berdasarkan kreteria yang telah disesuaikan dengan karakteristik pada TK Aisyiyah Batusangkar. Lihat Tabel 1.
Tabel 1 Kategori Peningkatan Pengetahuan Kognitif Anak [10]

\begin{tabular}{lll}
\hline Persentase & Kriteria & Nilai \\
\hline $90 \%-100 \%$ & Baik Sekali (BS) & 4 \\
$80 \%-89 \%$ & Baik (B) & 3 \\
$70 \%-79 \%$ & Cukup (C) & 2 \\
$<70 \%$ & Kurang (K) & 1 \\
\hline
\end{tabular}

SPSS. Uji T Paired merupakan uji komparatif data yang yang biasa disebut dengan istilah Pairing $\mathrm{T}$ Test. $\mathrm{T}$ Paired menguji beda parametris dua data yang berpasangan. Melalui analisis ini dapat diketahui seberapa besar korelasi pemanfaatan Augmanted Reality dapat mempengaruhi tingkat pengetahuan sains sederhana pada anak.

\section{Hasil Pembahasan}

Hasil penelitian menunjukkan ada perubahan cukup signifikan yang diperoleh melalui penerapan permainan Augmanted Reality terhadap pengetahuan sains sederhana anak. Penilaian pengetahuan tersebut didasarkan pada tujuh indikator yaitu terkait dengan ketertarikan anak dengan permainan Augmanted Reality, anak dapat menyebutkan kegunaan gambar, anak dapat mengelompokan gambar, anak dapat mengemukakan pendapatnya tentang percobaan yang dilakukan, anak dapat memprediksi urutan berikutnya, anak dapat bermain bersama dan percaya diri dalam melakukan kegiatan permainan Augmanted Reality, dan anak senang bermain Augmanted Reality. Penilaian terhadap ketujuh indikator tersebut dilakukan penghitungan sehingga dapat diperoleh nilai rata-rata untuk setiap pertemuan tindakan.

Dalam penelitian tindakan kelas ini, tindakan utama dalam pelaksanaan penelitian dimulai dengan penyusunan rencana kegiatan harian mulai dari kegiatan awal hingga kegiatan akhir. Pada awalnya, peneliti melakukan analisis kurikulum untuk menentukan indikator yang akan dikembangkan dalam permainan Augmanted Reality yang dipersiapkan dalam bentuk Rencana Kerja Mingguan (RKM) serta dijabarkan dalam bentuk Rencana Kerja Harian (RKH) yang berisikan tentang peningkatan pengenalanan sains sederhana pada anak.

Pada kondisi awal sebelum penelitian dan tindakan dilakukan ditemukan bahwa sebagian besar anak kurang tertarik dalam pembelajaran sains. Penilaian terhadap 20 orang anak berdasarkan ketujuh indikator tersebut mendapat nilai baik sebanyak $11 \%$, yang memperoleh nilai cukup $13 \%$, sedangkan $76 \%$ mendapat nilai kurang. Hal ini menunjukkan bahwa pada umumnya 
kemampuan pembelajaran sains melalui permainan Augmanted Reality belum mencapai kreteria ketuntasan minimum (KKM) yang ditetapkan yaitu $75 \%$. Lihat Gambar 2.

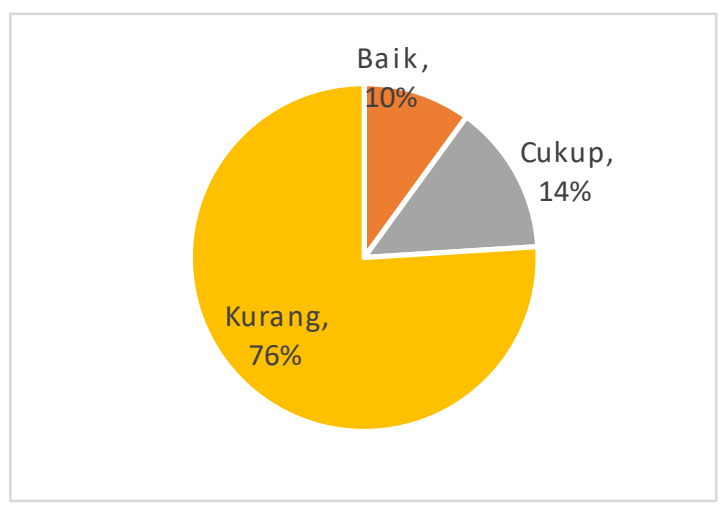

Gambar 2. Kondisi Pemahaman Anak Terhadap Sains Sederhana Sebelum Penelitian

Adapun pada kondisi awal ini tidak terdapat satu indikatorpun yang menunjukkan pemahaman anak dalam kondisi baik sekali (>90\%). Pada masa ini, hanya $5 \%$ anak yang memiliki nilai ketertarikan dengan alat permainan. $10 \%$ anak diketahui dapat menyebutkan kegunaan suatu benda, mengelompokkan benda dan senang bermain. $15 \%$ anak dapat memprediksi urutan berikutnya dan anak dapat bermain bersama dengan percaya diri. Sedangkan sisanya nilai anak cenderung cukup dan didominasi kurang.

Sebelum melakukan tindakan Siklus I, dilakukan Berdasarkan capaian hasil belajar yang diperoleh anak perencanaan dengan komponen-komponen indikator pada siklus II ditemukan tiga hal berikut, yaitu anak yang dikembangkan, kegiatan pembelajaran, alat dan senang dengan alat permainan Augmanted Reality dapat sumber serta penilaian, selanjutnya menentukan metode menyebutkan kegunaan gambar yang ditampilkan dalam pembelajaran yaitu bercakap-cakap, percobaan dan Augmanted Reality, dan mau melakukan percobaan. pratek langsung dengan mempersiapkan media Peningkatan ini dapat terlihat pada siklus II yang telah Augmanted Reality. Meski menunjukan peningkatan mencapai kreteria ketuntasan menimum yang telah pada akhir siklus I, namun masih ditemukan anak yang ditetapkan, ini dapat dilihat pada persentase nilai ratabelum tertarik dengan permainan Augmanted Reality, rata pada pertemuan siklus II sebagai berikut:

belum dapat mengemukakan pendapatnya tentang a. Pertemuan I anak yang mendapatkan nilai baik percobaan yang telah dilakukannya, serta anak belum percaya diri dalam melakukan permainan. Berdasarkan hal tersebut, peneliti menyusun perencanaan untuk pelaksanaan tindakan kelas siklus II dengan memperhatikan hal sebagai berikut :

1. Cara menyampaikan pembelajaran kepada anak masih perlu disempurnakan yaitu permainan yang disenangi anak, memakai media yang sesuai dengan perkembangan anak, serta dekat dengan anak, dan dilakukan dalam suasana yang menyenangkan.

2. Masih ada anak yang belum menyenangi permainan Augmanted Reality dan menemui kesulitan dalam melakukan percobaan, oleh karena itu pada siklus II guru perlu memberikan bimbingan yang lebih kepada anak agar anak lebih mudah mengerti.

Jurnal RESTI (Rekayasa Sistem dan Teknolo:
Hasil penelitian juga menunjukkan bahwa ada beberapa hal yang perlu disempurnakan pada Siklus II, yaitu sebagai berikut:

a. Ukuran alat peraga yang dipakai terlalu kecil sehingga anak mengalami kesulitan dalam melaksanakan kegiatan pembelajaran .

. Kondisi kurang kondusif karena dalam permainan anak ingin semuanya melakukan terlebih dahulu Jika guru kurang memperhatikan anak maka anak tidak akan percaya diri melakukan permainan

kemudian menjadi dasar bagi pelaksanaan siklus embelajaran memakai media yang sesuai dengan perkembangan nak, serta dekat dengan anak, dan dilakukan dalam kepada dorogan serta motivasi agar anak tidak bosan. belajaran anak usia dini haruslah berpusat kepada yang kondusf belajar agar potensi yang dimilikinya dapat dikembangkan melalui pembelajaran aktif. sekali $19 \%$ yang mendapat nilai baik $56 \%$, mendapat nilai cukup $19 \%$ dan nilai kurang $6 \%$.

b. Pertemuan II anak yang mendapat nilai amat baik $23 \%$ yang mendapat nilai baik $61 \%$, yang mendapat nilai cukup $14 \%$ dan nilai kurang $2 \%$

c. Pertemuan III anak yang mendapatkan nilai amat baik $27 \%$ yang mendapatkan nilai baik $63 \%$, yang mendapat nilai cukup $9 \%$ dan yang mendapat nilai kurang $1 \%$

Adapun hasil perbandingan pengetahuan sains anak mengalami peningkatan dari setiap pertemuannya, sebagaimana pada Gambar 3.

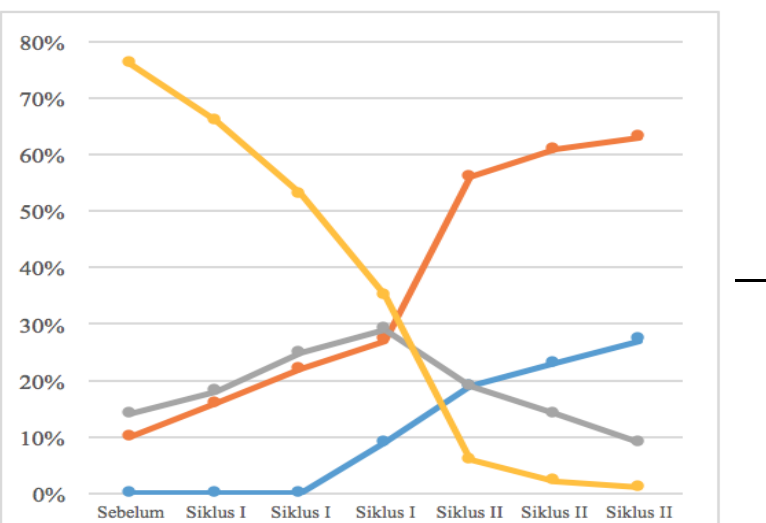


tindakan kelas berupa dua siklus tersebut. Peningkatan indikator tertinggi dapat dilihat adalah anak dapat menyebutkan kegunaan gambar dan mengelompokkan gambar. Sedangkan indikator lain, rata-rata meningkat 80\%-85\%. Lihat Tabel 2.

Tabel 2. Peningkatan Indikator Pemahaman Pengetahuan Anak Terhadap Sains Sederhana

Gambar 3. Grafik Peningkatan Pemahaman Sain Sederhana Anak Selama Siklus Penelitian

Gambar 3 menunjukan grafik perkembangan kemampuan kognitif anak dari sebelum tindakan hingga Siklus Kedua Pertemuan Ketiga. Berdasarkan grafik diatas terlihat bahwa ada peningkatan persentase yang sangat signifikan pada kategori Baik dan Baik Sekali serta penurunan pada kategori cukup dan kurang. Pada kondisi sebelum tindakan hasil observasi terhadap pengenalan sains anak didominasi oleh kriteria kurang (76\%) dan cukup (14\%), hal ini berbanding terbalik dengan kondisi pada siklus kedua pertemuan ketiga. Secara konstan, tiap pertemuan berhasil meningkatkan persentase kategori baik dan baik sekali dari $0 \%$ kategori baik sekali dan $10 \%$ kategori baik, menjadi $27 \%$ kategori baik sekali dan $63 \%$ kategori baik diakhir pertemuan.

Uraian diatas menunjukkan bahwa permainan Augmanted Reality untuk meningkatkan pengenalan sains anak dilihat dari rata-rata pencapaian kemampuan secara keseluruhan sudah tercapai kreteria ketuntasan menimum (KKM). Peningkatan pengenalan sains sederhana di Taman Kanak-kanak Aisyiyah Batusangkar terjadi mulai dari kondisi awal, Siklus I dan Siklus II yaitu 90\%. Berarti permainan Augmanted Reality dapat meningkatkan pengenalan sains sederhana pada Anak Usia Dini di Taman Kanak-kanak Aisyiyah Batusangkar melebihi Kreteria Ketuntasan Menimum (KKM) $75 \%$.

Dengan merujuk pada konversi nilai dimana sangat baik dilambangkan dengan angka 4 dan pemahaman yang kurang dilambangkan dengan skor 1, maka terlihat bahwa rata-rata nilai pemahaman sains sederhana anak sebelum dilakukan penelitian adalah 1.5080. Angka ini secara signifikan meningkat pada akhir pertemuan dengan rata-rata atas 20 anak sebesar 3.1155.

\begin{tabular}{llc}
\hline $\begin{array}{l}\text { Indikator Pemahaman Pengetahuan Anak } \\
\text { terhadap Sains Sederhana }\end{array}$ & $\begin{array}{c}\text { Persentase } \\
\text { Pengetahuan Anak } \\
\text { terhadap Sains } \\
\text { Sederhana }\end{array}$ \\
\cline { 2 - 3 } & $\begin{array}{c}\text { Sebelum } \\
\text { Tindakan }\end{array}$ & $\begin{array}{l}\text { Sesudah } \\
\text { Tindakan }\end{array}$ \\
\hline $\begin{array}{l}\text { Anak tertarik dengan alat permainan } \\
\text { Augmanted Reality }\end{array}$ & $5 \%$ & $90 \%$ \\
$\begin{array}{l}\text { Anak dapat menyebutkan gambar } \\
\text { Anak dapat mengelompokan gambar }\end{array}$ & $10 \%$ & $95 \%$ \\
$\begin{array}{l}\text { Anak dapat mengemukakan pendapatnya } \\
\text { tentang percobaan yang dilakukan }\end{array}$ & $5 \%$ & $95 \%$ \\
$\begin{array}{l}\text { Anak dapat memprediksi urutan berikut } \\
\text { Anak dapat bermain bersama dan percaya } \\
\text { diri dalam melakukan permainan }\end{array}$ & $15 \%$ & $85 \%$ \\
Anak senang bermain Augmanted Reality & $15 \%$ & $90 \%$ \\
\hline
\end{tabular}

Permainan dengan Augmanted Reality terbukti dapat meningkatkan kemampuan pengenalan anak terhadap sains sederhana. Namun kemampuan guru merupakan aspek yang juga penting daam mengembangkan kemampuan anak. Strategi pembelajaran yang menyenangkan akan memberi kontribusi terhadap hasil belajar anak dalam upaya mengembangkan sains anak sehingga kecerdas an anak meningkat.

Suasana lingkungan juga merupakan hal yang mempengaruhi peningkatan kemampuan anak. Situasi yang kondusif dan dilakukan dengan pola bermain sambil belajar akan dapat mengembangkan perkembangan bahasa, kognitif dan motorik halus anak sehingga informasi yang diterima anak dapat diaplikasikan secara langsung. Selain itu alat peraga/media pembelajaran yang menarik dan bervariasi yang dekat dengan anak membuat anak senang serta percaya diri dalam melakukan kegiatan.

\section{Kesimpulan}

\subsection{Simpulan}

Berdasarkan hasil penelitian yang telah dilaksanakan tentang pengenalan sains melalui Augmanted Reality dapat disimpulkan bahwa penerapan strategi pembelajaran dalam upaya peningkatan perkembangan sains anak melalui permainan dengan media Augmanted Reality, telah berhasil meningkatkan pengenalan sains Hasil analis is T Paired menunjukkan bahwa nilai Sig. (2- anak dalam belajar. Pada awalnya rata-rata pemahaman tailed) yaitu $0.00<0.05$, maka dapat disimpulkan bahwa terdapat perbedaan signifikan antara sebelum dan sesudah permainan dengan menggunakan Augmanted Reality.

Ditinjau berdasarkan tujuh indikator yang telah disebutkan tadi, ketujuh indikator tersebut mengalami peningkatan yang cukup signifikan setelah melewati anak terhadap sains pada ketujuh indikator adalah $10 \%$, angka ini meningkat pesat setelah penelitian menjadi $90 \%$. Peningkatan pengenalan sains anak dapat dilihat dari peningkatan nilai anak, serta peningkatan persentase jumlah anak yang mendapat nilai yang lebih baik sebelum dilakukan tindakan.Hasil penelitian ini juga mengungkapkan bahwa strategi pembelajaran yang menyenangkan dengan memakai sarana belajar

Jurnal RESTI (Rekayasa Sistem dan Teknologi Informasi) Vol . 2 No. 1 (2018) 403 - 409 
Erna

Jurnal RESTI (Rekayasa Sistem dan Teknologi Informasi) Vol . 2 No. 1 (2018) 403 - 409

permainan Augmanted Reality juga membantu berhubungan dengan percobaan-percobaan dalam meningkatkan hasil belajar anak. Alat permainan pembelajaran untuk meningkatkan pengenalan sains Augmanted Reality selain meningkatkan sains anakjuga anak. Ketiga disarankan kepada guru-guru di masa yang dapat meningkatkan kemampuan kognitif, bahasa akan datang untuk dapat mengeksploitasi lebih motorik halus, serta dapat mengembangan sosial- mendalam tentang alat permaian dengan Augmanted emosional anak dalam bermain

Reality sehingga pengenalan sains anak akan lebih

Perkembangan sains anak Taman Kanak-kanak

Aisyiyah Batusangkar setelah dilaksanakan penelitian tindakan kelas menunjukkan hasil yang lebih baik sehingga anak tertarik dengan permainan Augmanted Reality dapat menyebutkan kegunaan Augmanted Reality, mengelompokkan benda, dapat memprediksi urutan berikutnya serta anak percaya diri dan senang melakukan kegiatan percobaan

Berdasarkan uraian di atas, dapat diambil kesimpulan akhir dari penelitian ini bahwa penelitian tindakan kelas yang dilaksanakan melalui permainan Augmanted Reality dapat membantu pengenalan sains sederhana anak Taman Kanak-kanak Aisyiyah Batusangkar.

\subsection{Saran}

Berdasarkan pembahasan kesimpulan yang telah diperoleh dalam penelitian ini dapat diberikan saransaran sebagai berikut, pertama, disarankan kepada para guru untuk dapat mencoba cara-cara yang diterapkan dalam penelitian ini, dengan berbagai cara dan variasinya dalam pembelajaran di sekolah. Kedua disarankan kepada pihat sekolah supaya menyediakan alat permainan dan alat peraga khususnya yang

\section{DAFTAR PUSTAKA}

[1] Undang-undang Nomor $20 \mathrm{~T}$ ahun 2003 Tentang Sistem Pendidikan Nasional

[2] Sujiono, Yuliani, Nuriani. Dkk. 2006. Metode Pengembangan kognitif. Jakarta: Universitas Terbuka

[3] Nugraha, Ali. 2005. Pengembangan Pembelajaran Sains Pada Anak Usia Dini. Jakarta: Depdiknas

[4] Musbikin, Imam. 2010. Buku Pintar PAUD. Yogjakarta: Laksana.

[5] Nazrudin, S. 2012, Android Pemrograman Aplikasi Mobile Smart phone dan Tablet PC Berbasis Android. Bandung: InformatikaBandung

[6] Depdiknas, 2004. Sosialisasi Pendidikan Anak Usia Dini. Jakarta: Depdiknas.

[7] Aisyah, Siti, Dkk. 2007.Perkembangan dan Konsep Dasar Pengembangan Anak Usia Dini. Jakarta: Universitas Terbuka.

[8] Dwijana,Widarmi.2008.Kurikulum Anak Usia Dini. Jakarta: Universitas Terbuka.

[9] Arikunto, Suharsimi, 1995. Manajemen Penelitian. Jakarta: Rineka Cipta

[10] Arikunto, Suharsimi, 1995. Manajemen Penelitian. Jakarta: Rineka Cipta 